\title{
DEGRADATION OF LEAF LITTER PHENOLICS BY AQUATIC AND TERRESTRIAL ISOPODS
}

\author{
MARTIN ZIMMER, ${ }^{1, *}$ RICARDO OLIVEIRA, ${ }^{2}$ ELSA RODRIGUES, ${ }^{2}$ \\ and MANUEL A. S. GRAÇA ${ }^{2}$ \\ ${ }^{1}$ Zoologisches Institut: Limnologie, Christian-Albrechts-Universität zu Kiel, Olshausenstr. \\ 40, D-24098 Kiel, Germany \\ ${ }^{2}$ Departamento de Zoologia and IMAR, Universidade de Coimbra, 3004-517 Coimbra, \\ Portugal
}

( Received June 3, 2004; revised February 11, 2005; accepted April 15, 2005)

\begin{abstract}
To investigate species-specific decomposition rates of litter from native (Quercus faginea) and introduced (Eucalyptus globulus) tree species in Portugal, we monitored changes in the phenolic signature of leaf litter during decomposition as mediated by an aquatic, Proasellus coxalis (Isopoda: Asellota), and two terrestrial, Porcellio dispar and Eluma caelatum (Isopoda: Oniscidea), detritivores. Although the litter of Eucalyptus and Quercus did not differ in overall protein precipitation capacity, we detected differences in terms of contents of particular phenolic compounds and phenol oxidation products. Accordingly, we observed food-specific consumption rates in Proasellus, but not in the terrestrial isopods. Proasellus digested Eucalyptus at significantly higher rates than Quercus, whereas the opposite was the case for Eluma, and Porcellio digested both litter types equally well. Despite slight differences in detail, effects of Proasellus on changes in the signature of litter phenolics were similar for both litter types, whereas terrestrial isopods-Porcellio and Eluma, although they differed from each otherdigestively degraded phenolic compounds in Eucalyptus and Quercus litter, respectively, in different ways. Overall, however, degradation of litter phenolics was similarly effective on both litter types. From these data, we conclude that decomposition of Eucalyptus litter does not proceed more slowly than of litter from native Portuguese trees.
\end{abstract}

Key Words-Animal-microbe interactions, decomposition, Eucalyptus, Isopoda, neophytes, phenolics, Quercus, tannin degradation.

* To whom correspondence should be addressed. E-mail: mzimmer@zoologie.uni-kiel.de 


\section{INTRODUCTION}

Eucalyptus globulus Labill., native in Australia, has been planted during the last $170 \mathrm{yr}$ in southern European countries, South America, and other parts of the world. In Portugal, Eucalyptus plantations nowadays occupy more than $20 \%$ of the forested area (Canhoto et al., 2002). Several studies demonstrated that Eucalyptus plantations affect invertebrate assemblages in soils (e.g., Pinto et al., 1997; Sousa et al., 1997) and freshwaters (e.g., Abelho and Graça, 1996; Graça et al., 2002). In freshwaters, invertebrate shredders may exert an important contribution to the decomposition of leaves entering streams (Graça, 2001); however, invertebrate shredders seem to have difficulties feeding on E. globulus leaves (Graça et al., 2002). In soil, terrestrial isopods apparently have the same difficulty using E. globulus litter (Sousa, personal communication). Eucalyptus litter is, therefore, considered a low-quality food for both freshwater (Mellilo et al., 1982; Campbell and Fuchshuber, 1995) and soil (Sousa, personal communication) detritivores. Such effects may be due to chemical and physical defense mechanisms in leaves. Canhoto and Graça (1999) showed that eucalyptus oils inhibit fungal growth and invertebrate feeding, and a thick cuticle retards microbial colonization of senescent leaves.

Another chemical defense of E. globulus leaves is polyphenolics. Canhoto and Graça (1996) observed a strong negative correlation between the phenol content of different native litter types and Eucalyptus litter and decomposition rates in a stream, whereas Canhoto and Graça (1999) showed that polyphenolics from eucalypt leaves decrease feeding by detritivores. Thus, effects of phenolics on detritivores may be one reason for the low decomposability of Eucalyptus litter. Overall, however, Eucalyptus litter decomposed at almost two times higher rates than the Portuguese oak, Quercus faginea Lam., the latter containing more than twice as much phenolics than the former but about the same amount of nitrogen (Canhoto et al., 2002). In the present study, we used leaf litter of the native Portuguese oak, $Q$. faginea, and the introduced $E$. globulus (both henceforth mentioned generically) to study in detail changes in the content of specific phenolic compounds during decomposition as mediated by aquatic and terrestrial detritivores.

Both terrestrial Oniscidea and freshwater Asellota had ancestors in the marine environment (that may have been closely related; Zimmer and Bartholmé, 2003). It has recently been discussed to what extent the ability to tolerate or even digest phenolic food compounds may have been important in the evolutionary step to utilizing terrestrial food sources (Zimmer et al., 2002a,b); despite their aquatic lifestyle, freshwater isopods mostly consume leaf litter of terrestrial origin (cf. Zimmer and Bartholmé, 2003) just like their terrestrial relatives do (cf. Zimmer, 2003). We were, thus, interested in whether representatives of different phylogenetic histories that are similar with respect to 
available food sources are also similar in their digestive capabilities. Hence, we chose two terrestrial and one freshwater isopods as common Portuguese models for evolutionary ecological studies on digestive capabilities and detritivoremicrobe interactions and their consequences for decomposition processes, in particular the degradation of phenolic leaf litter compounds.

\section{METHODS AND MATERIALS}

Leaf Litter and Detritivores. We collected leaf litter in spring 2002, when isopods were active in the field and started reproducing, in the Mata Nacional do Choupal, Coimbra $\left(40^{\circ} 12^{\prime} 33^{\prime \prime} \mathrm{N}, 8^{\circ} 90^{\prime} 27^{\prime \prime} \mathrm{W}\right)$, Central Portugal. At this time of the year, with high feeding rates by isopods, Quercus litter had been lying on the ground for about 1-3 mo, whereas Eucalyptus litter was estimated to be up to 6 mo old. Thus, our choice of litter reflected the natural conditions detritivores face during their most active feeding period; many, but not all, species-specific compounds of the litter will have been leached at that stage. We selected leaves that did, upon visual inspection, not show heavy decomposition. In the laboratory, leaves were air-dried in the dark at room temperature and stored dry until needed to avoid further loss of phenolics through leaching or photoautoxidation. We did not test for differences in phenolic signatures of leaf litter before and after storage because we were interested in relative effects of detritivore activity on phenolic litter compounds during decomposition.

Terrestrial isopods, Porcellio dispar Verhoeff 1901 (Oniscidea: Porcellionidae) and Eluma caelatum [Miers 1877] (Oniscidea: Armadillidiidae), were collected in the Mata Nacional do Choupal by browsing through mixed leaf litter layers in spring 2002. In the laboratory, they were housed in plastic boxes with moist sand $\left(16^{\circ} \mathrm{C}\right)$ feeding exclusively on Quercus or Eucalyptus for at least 5 d. Proasellus coxalis [Dollfus 1892] (Asellota: Asellidae) were collected in a small creek, Rio Pavia in Fail $\left(40^{\circ} 36^{\prime} 17^{\prime \prime} \mathrm{N}, 7^{\circ} 58^{\prime} 44^{\prime \prime} \mathrm{W}\right)$, near Viseu, northeast of Coimbra, which belongs to the Mondego's drainage basin. In the laboratory, they were housed in plastic boxes with aerated water of the same origin $\left(16^{\circ} \mathrm{C}\right)$ feeding exclusively on Quercus or Eucalyptus for at least $5 \mathrm{~d}$.

Experimental Setup. During experiments $(N=9$, each), groups of three (terrestrial) or five (aquatic) isopods were kept in small petri dishes, the lids of which were lined with moist filter paper to maintain high humidity or that were filled with filtered creek water, respectively. Feces were collected twice a day to minimize both coprophagy and postdigestive changes in phenolic compounds by picking up fecal pellets with forceps or by filtering the water from the petri dishes after removal of isopods and litter, respectively. Afterwards, isopods 
were placed in fresh petri dishes with filter paper-lined lids or filtered creek water, respectively. Feces were immediately stored at $-20^{\circ} \mathrm{C}$ until being used for HPLC analysis.

Single air-dried leaves, randomly chosen from the pool of hand-selected litter (see above), were cut in pieces, two of which were weighed and then placed in either isopod assays or isopod-free controls. Another piece of that same leaf was used to determine the initial phenolic signature of individual leaves as described below. An additional piece of each leaf was weighed, then oven-dried $\left(60^{\circ} \mathrm{C}, 24 \mathrm{hr}\right)$, and weighed again to obtain a factor to estimate the initial dry mass of litter (Zimmer and Huryn, in press). After the experiment, lasting for $5 \mathrm{~d}$, litter remnants were weighed fresh to calculate mass loss. Litter obtained from parallel experiments that were not used for HPLC analysis was used to determine a factor for the estimation of final dry mass of litter (oven drying at $60^{\circ} \mathrm{C}$ for $24 \mathrm{hr}$ ) as described above.

Consumption rates $\left[\mathrm{mg}\left(\mathrm{mg} \mathrm{d}^{-1}\right]\right.$ were determined based on litter mass loss and mean isopod dry mass. Digestibility (\%) was determined as percent of ingested litter that was not egested as feces (Zimmer and Huryn, in press). Direct effects of detritivores on litter chemistry through digestion were quantified by comparing the phenolic signature of litter prior to the experiment with that of isopod feces. Indirect effects of detritivores on litter chemistry (e.g., through mediating microbial decomposition; see Zimmer et al., 2002b, 2004) were estimated by comparing the phenolic signature of litter prior to the experiment with that of unconsumed litter remnants after the experiment. Such indirect effects could have occurred either through selective consumption of litter or through direct influences of detritivores (e.g., fecal amount and composition, mucus, urine, molt deposition, and so on) on type and abundance of microbiota (Zimmer et al., 2002b, 2004).

Leaf Litter Phenolics. For extraction of phenolics, 45-55 mg (dry mass) of leaf litter or $3-10 \mathrm{mg}$ of feces were homogenized in $2 \mathrm{ml} 50 \%$ aqueous methanol (cf. Van Alstyne, 1995) and shaken for $3 \mathrm{hr}$ at $16^{\circ} \mathrm{C}$. After centrifugation, the

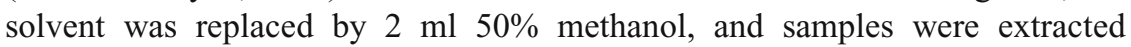
overnight at $16^{\circ} \mathrm{C}$. After centrifugation $(10,000 \times g, 10 \mathrm{~min})$, supernatants were pooled and either used for the determination of protein precipitation capacity or for HPLC analysis after filtering $(0.45 \mu \mathrm{m})$.

The capability of phenolics to precipitate proteins was measured using the radial diffusion assay (Hagerman, 1987). Portions of $9.5 \mathrm{ml}$ of agarose (1\%) containing $0.1 \%$ of bovine serum albumin (BSA) were dispensed in $8.5-\mathrm{cm}$ diam petri dishes. Polyphenolics were extracted from $50 \mathrm{mg}$ of leaf powder as described above. Aliquots of the supernatant $(36 \mu \mathrm{l})$ were inoculated into 4-mm diam wells punched out from the agar plate. A protein precipitation ring was allowed to develop for $3 \mathrm{~d}$ at $16^{\circ} \mathrm{C}$. The precipitation area was measured and compared to a standard curve using tannic acid (Merck; Ref.: 1.00773.0250; 
Lot K18722673703), and the results were expressed in terms of "tannic acid equivalents." We are aware that different phenolic compounds will have different protein precipitation capacities, but because we could not determine most of the compounds, we refrained from using different standards.

For the detection of specific phenolic compounds in litter and feces extracts, we performed RP-HPLC using a Brownlee Column (Applied Biosystems) SPHERI-5 RP-18 $(5 \mu \mathrm{m}) 250 \times 4.6(\mathrm{OD}-5 \mathrm{~A})$ with a NewGuard RP-18 $(7 \mu \mathrm{m})$ $15 \times 3.2$ guard column. Peaks were detected at $280 \mathrm{~nm}$. In preruns, no peaks were detected after $45 \mathrm{~min}$; thus, we chose a run time of $45 \mathrm{~min}$. According to previous studies (Scalbert et al., 1988; Streit and Fengel, 1994) and our own preexperiments, we chose a system of two eluants [A, 950:49:1, water/methanol/ phosphoric acid (85\%); B, 999:1, methanol/phosphoric acid (85\%)] with a gradient of $0-5 \%$ B during the first $15 \mathrm{~min}$ and a subsequent gradient of $5-90 \% \mathrm{~B}$ during $15 \mathrm{~min}$ at a flow rate of $1 \mathrm{ml} \mathrm{min}^{-1}$ at $20^{\circ} \mathrm{C}$.

Besides other phenolic compounds, tannic acid (mainly penta-galloylglucose), gallic acid, catechin, and gallocatechin have been isolated from Quercus leaves (e.g., Scalbert et al., 1988; Tanaka et al., 1995). We used these compounds (Sigma) as standards for HPLC in concentrations of $0.1,0.5$, and $1.0 \mathrm{mg} \mathrm{ml}^{-1}$. Because tannic acid, rutin, quercetin, and catechol have, besides others, been determined in extracts of Eucalyptus leaves (e.g., Conde et al., 1997; Sasikumar et al., 2002), we used these compounds (Sigma) as standards in HPLC $\left(0.1,0.5\right.$, and $\left.1.0 \mathrm{mg} \mathrm{ml}^{-1}\right)$. To detect oxidation products of these model phenolics in experimental extracts, we forced phenol oxidation in standards by both vigorously shaking these solutions for $60 \mathrm{~min}$ at RT and adding $\mathrm{NaOH}$ solution $\left(32 \%, \mathrm{pH} 12 ; 1 \mathrm{ml} 100 \mathrm{ml}^{-1}\right)$. After the generation of brown coloration, we determined the elution time of phenol-specific oxidation products by HPLC as described above.

Even with the slowly changing conditions during min 0-15 (see above), we could not unambiguously identify every single peak derived from a complex mixture of litter phenolics and their derivates (see Table 1). Difficulties in separating phenolic compounds by RP-HPLC with water-methanol gradients have previously been reported in flowers by Van de Casteele et al. (1983), in leaves by Koupai-Abyazani et al. (1992), and in wood by Streit and Fengel (1994). We, thus, refrain from assigning phenolic standards to particular HPLC peaks, but refer to phenolic compounds by the name of peaks in order of their elution.

From the areas (units $\mathrm{ml}^{-1}$ ) of particular peaks as revealed by HPLC analysis of pre- and postexperimental litter and feces, we approximated changes in the content of particular phenolic compounds (\%) in isopod-free controls, through isopod-mediated microbial activity, and through isopod feeding and digestion. Further, we estimated litter decomposition in terms of mass loss by calculating consumption rates of detritivores as described in Zimmer and Huryn 
Table 1. Assignment of Standard Phenolic Compounds ${ }^{a}$ to HPlC Peaks

\begin{tabular}{llllllllllll}
\hline & $\mathrm{C}$ & $\mathrm{D}$ & $\mathrm{E}$ & $\mathrm{F}$ & $\mathrm{G}$ & $\mathrm{H}$ & $\mathrm{M}$ & $\mathrm{O}$ & $\mathrm{P}$ & $\mathrm{R}$ & $\mathrm{U}$ \\
\hline GA & & & & & $\mathrm{X}$ & & & & & \\
TA & $\mathrm{X}$ & $\mathrm{X}$ & $\mathrm{X}$ & $\mathrm{X}$ & & & & & & \\
CAT & $\mathrm{X}$ & & & & & & & & & \\
CATol & $\mathrm{X}$ & & & & & $\mathrm{X}$ & & & & \\
gCAT & $\mathrm{X}$ & $\mathrm{X}$ & & & & & & & & \\
$\begin{array}{l}\text { oxGA } \\
\text { oxTA }\end{array}$ & & & & & & & $\mathrm{X}$ & $\mathrm{X}$ & & \\
$\begin{array}{l}\text { oxCAT } \\
\text { oxCATol }\end{array}$ & $\mathrm{X}$ & & & & & & & $\mathrm{X}$ & & \\
oxgCAT & & & & & & & & & & $\mathrm{X}$ & $\mathrm{X}$ \\
\hline
\end{tabular}

${ }^{a} \mathrm{GA}$, gallic acic; TA, tannic acid; CAT, catechin; CATol, catechol; gCAT, gallocatechin; ox-, oxidation product of -. Other standard compounds could not be assigned to HPLC peaks from experimental samples.

(in press). Because most of our data deviated from normal distribution, we chose median \pm median absolute deviation for graphical presentation, and nonparametric tests were used for statistical analysis. Comparison of different treatments (leaf litter or detritivore species) was performed through Mann-Whitney $U$-tests. Differences between initial values and values after experimental treatment were tested with Wilcoxon sign tests.

\section{RESULTS}

General Patterns. Although Quercus and Eucalyptus litter did not differ from each other quantitatively in their initial protein precipitation capacity (radial diffusion assay: Eucalyptus, $24 \pm 4 \mathrm{mg}$ TA equivalents $\mathrm{g}^{-1}$; Quercus, $18 \pm$ $\left.8 \mathrm{mg} \mathrm{g}^{-1} ; P>0.7\right)$, they differed qualitatively in terms of contents of different phenolic species and their oxidation products (Figure 1).

While microbial degradation (in animal-free assays) of Quercus leaves was not detectable in the terrestrial environment, litter lost $2 \pm 1 \mu \mathrm{g}(\mathrm{mg} \mathrm{d})^{-1}$ in the aquatic environment $(P<0.05)$, presumably because of microbial degradation and leaching. After correction of data for these control values, Porcellio $[4 \pm$ $\left.2 \mu \mathrm{g}(\mathrm{mg} \mathrm{d})^{-1}\right]$, Eluma $\left[7 \pm 3 \mu \mathrm{g}(\mathrm{mg} \mathrm{d})^{-1}\right]$, and Proasellus $\left[3 \pm 2 \mu \mathrm{g}(\mathrm{mg} \mathrm{d})^{-1}\right]$ did not differ from each other with respect to consumption rates $(P>0.3)$. Digestibility of Quercus litter was similar in Porcellio $(33 \pm 17 \%)$ and Proasellus $(31 \pm 24 \%)$, but significantly higher $(P<0.05)$ in Eluma $(62 \pm 22 \%)$.

Microbial degradation and leaching (in animal-free assays) of Eucalyptus resulted in litter mass loss of $4 \pm 1 \mu \mathrm{g}(\mathrm{mg} \mathrm{d})^{-1}$ in the terrestrial environment and $11 \pm 9 \mu \mathrm{g}(\mathrm{mg} \mathrm{d})^{-1}$ in the aquatic environment $(P<0.01)$. After correction 

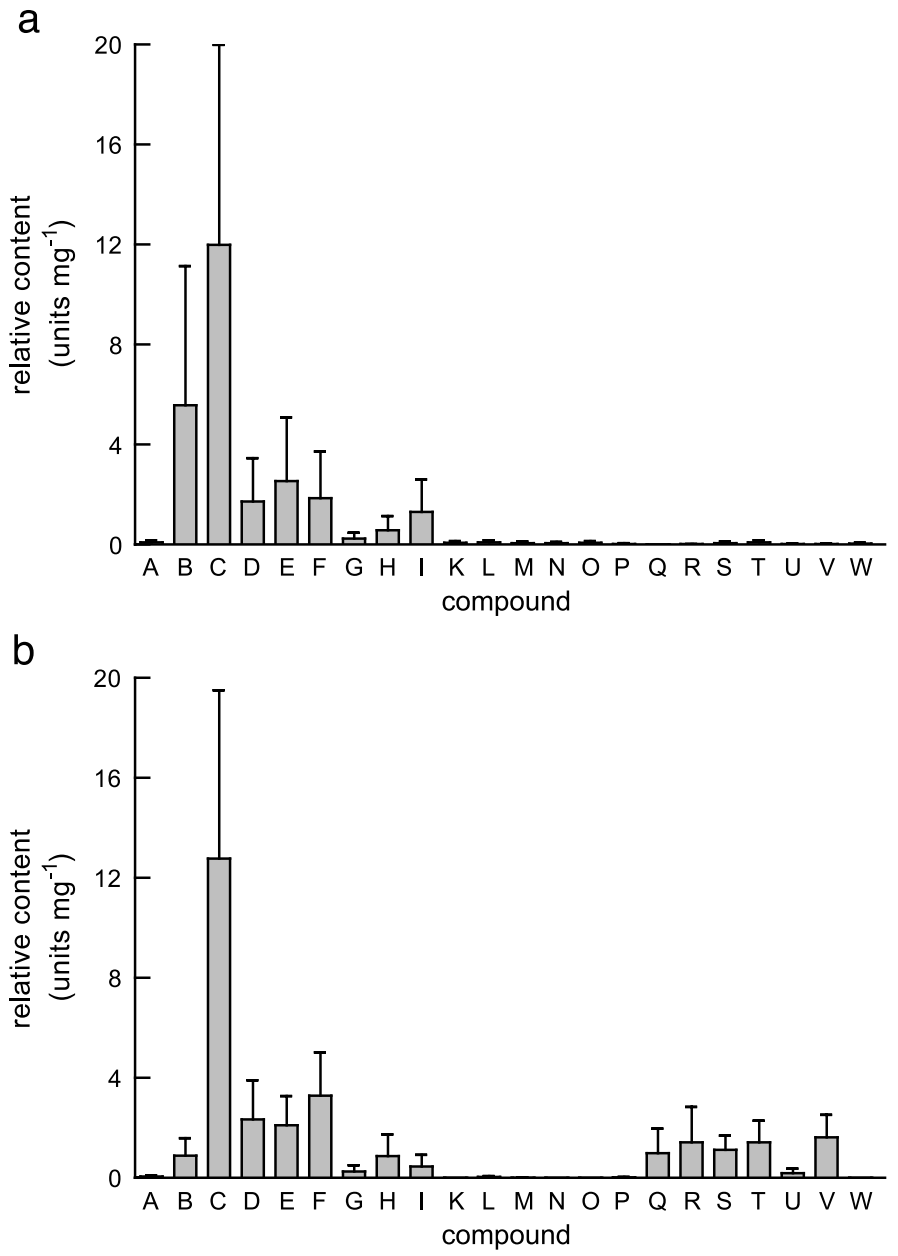

FIG. 1. Phenolic composition of leaf litter derived from Quercus (a) and Eucalyptus (b). Data are median \pm median absolute deviation $(N=9)$.

of data for control values, Porcellio $\left[5 \pm 3 \mu \mathrm{g}(\mathrm{mg} \mathrm{d})^{-1}\right]$ and Eluma $[3 \pm 2 \mu \mathrm{g}$ $\left.(\mathrm{mg} \mathrm{d})^{-1}\right]$ did not differ from each other with respect to consumption rates $(P>0.4)$, whereas Proasellus $\left[30 \pm 20 \mu \mathrm{g}\left(\mathrm{mg} \mathrm{d}^{-1}\right]\right.$ consumed about 10 times more than the terrestrial isopods. Thus, while the terrestrial isopods consumed about the same amounts of Quercus and Eucalyptus, Proasellus ingested significantly more Eucalyptus than Quercus $(P<0.01)$. Digestibility of Eucalyptus litter was similar in Porcellio $(33 \pm 13 \%)$ and Eluma $(26 \pm 20 \%)$, but significantly higher $(P<0.05)$ in Proasellus $(71 \pm 18 \%)$. Thus, Porcellio di- 
gested both litter types equally well, whereas Eluma was significantly $(P<0.01)$ more efficient in digesting Quercus, and Proasellus digested Eucalyptus at significantly $(P<0.01)$ higher rates than Quercus.

According to these results, Proasellus ingested larger amounts of Eucalyptus than Quercus. Consumption of Eucalyptus differed between consumers, with Proasellus consuming the largest amounts, but Quercus was ingested in similar rates by all consumers. Accordingly, digestibility of Eucalyptus by Proasellus was higher than that of Quercus. By contrast, although Eluma, too, exhibited higher digestibility of Eucalyptus than Porcellio, the terrestrial species digested both litter types equally well.

\section{General Changes in Phenolic Signatures}

Quercus. In the aquatic environment, only compounds B, C, E, I, P, and W were not completely or at least mostly leached, degraded, or transformed in animal-free controls (Figure 2a); compounds E, P, and W were obtained in higher concentration after the experiment than before $(P<0.05)$. With isopods present, compounds $\mathrm{C}$ and I were microbially degraded or transformed in the leaf litter that was not consumed by isopods (Figure 3a); microbially processed litter was enriched in compounds $\mathrm{N}, \mathrm{P}, \mathrm{U}$, and $\mathrm{V}(P<0.01)$. On average, compounds $\mathrm{B}$ and I were digested completely by litter-feeding isopods (Figure 4a), whereas compounds E, F, H, M, P, T, and V were concentrated higher in feces than in the litter $(P<0.01)$.

In the terrestrial environment, only a few compounds were lost through leaching, degradation, or transformation in animal-free controls (Figure 5a); compounds $\mathrm{D}, \mathrm{P}$, and $\mathrm{U}$ were obtained in higher concentration after the experiment than before $(P<0.001)$. With Porcellio present, compounds I, V, and W were microbially degraded, and compounds E, M, and P became significantly reduced, probably through microbial activity, in the leaf litter that was not consumed by isopods (Figure 6a); microbially processed litter was enriched in compounds L and $\mathrm{O}(P<0.05)$. With Eluma present, compounds D, E, F, O, and $\mathrm{T}$ were microbially degraded (Figure 7a), whereas compounds $\mathrm{M}, \mathrm{P}, \mathrm{U}$, and V became enriched in the litter $(P<0.001)$. On average, compounds $\mathrm{C}, \mathrm{U}$, and $\mathrm{V}$ were digested completely in isopod guts, and about 90 and $50 \%$ of compounds E and I, respectively, was degraded digestively by Porcellio (Figure 8a), whereas compounds D, F, G, H, M, P, R, S, and T were concentrated higher in feces than in the litter $(P<0.01)$. Eluma digested all of the remaining compounds $\mathrm{B}$, $\mathrm{G}, \mathrm{H}, \mathrm{I}, \mathrm{O}, \mathrm{T}$, and $\mathrm{V}$ and reduced compound D by about $85 \%$ (Figure $9 \mathrm{a}$ ), but led to a relative increase of compounds E, M, P, Q, R, U, and $\mathrm{W}(P<0.001)$.

Eucalyptus. In the aquatic environment, only compounds B, C, E, H, P, $\mathrm{U}$, and $\mathrm{W}$ were not completely or at least heavily leached or degraded in animal-free controls (Figure 2b); compounds $\mathrm{H}, \mathrm{P}$, and U were obtained in higher 

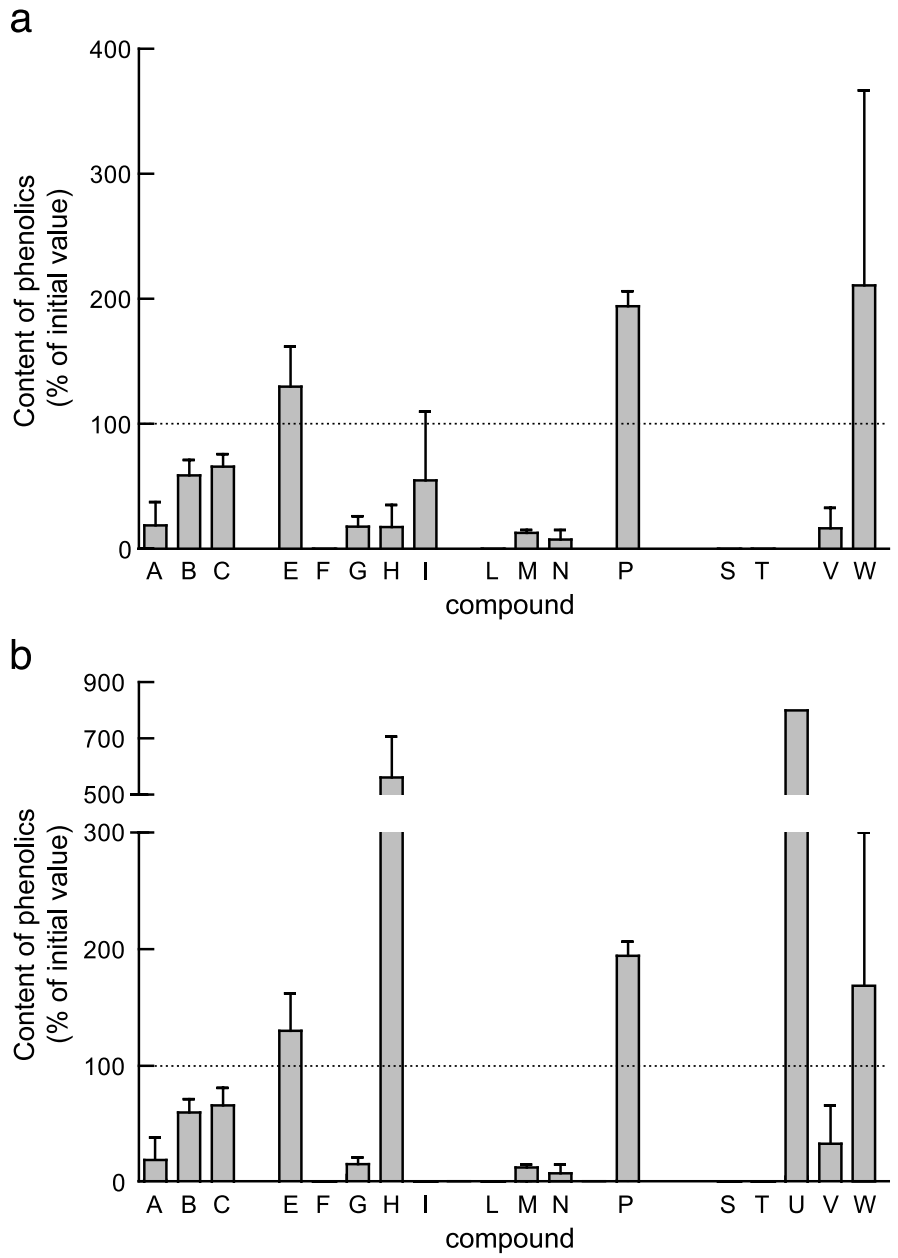

FIG. 2. Change in content of phenolic compounds in leaf litter derived from Quercus (a) and Eucalyptus (b) due to leaching and microbial processing within $5 \mathrm{~d}$ in aquatic animal-free control assays as compared with initial values of the litter (100\%). Data are median \pm median absolute deviation $(N=9)$. Only those peaks are listed along the $X$-axis that were found in the samples studied here.

concentration after the experiment than before $(P<0.001)$. With isopods present, compound A was microbially degraded or transformed in the leaf litter that was not consumed by isopods (Figure $3 \mathrm{~b}$ ); microbially processed litter was enriched in compounds $\mathrm{N}, \mathrm{P}$, and $\mathrm{U}(P<0.01)$. On average, compound $\mathrm{C}$ was digested completely during isopod gut passage, and about $30 \%$ of compound $\mathrm{E}$ was 

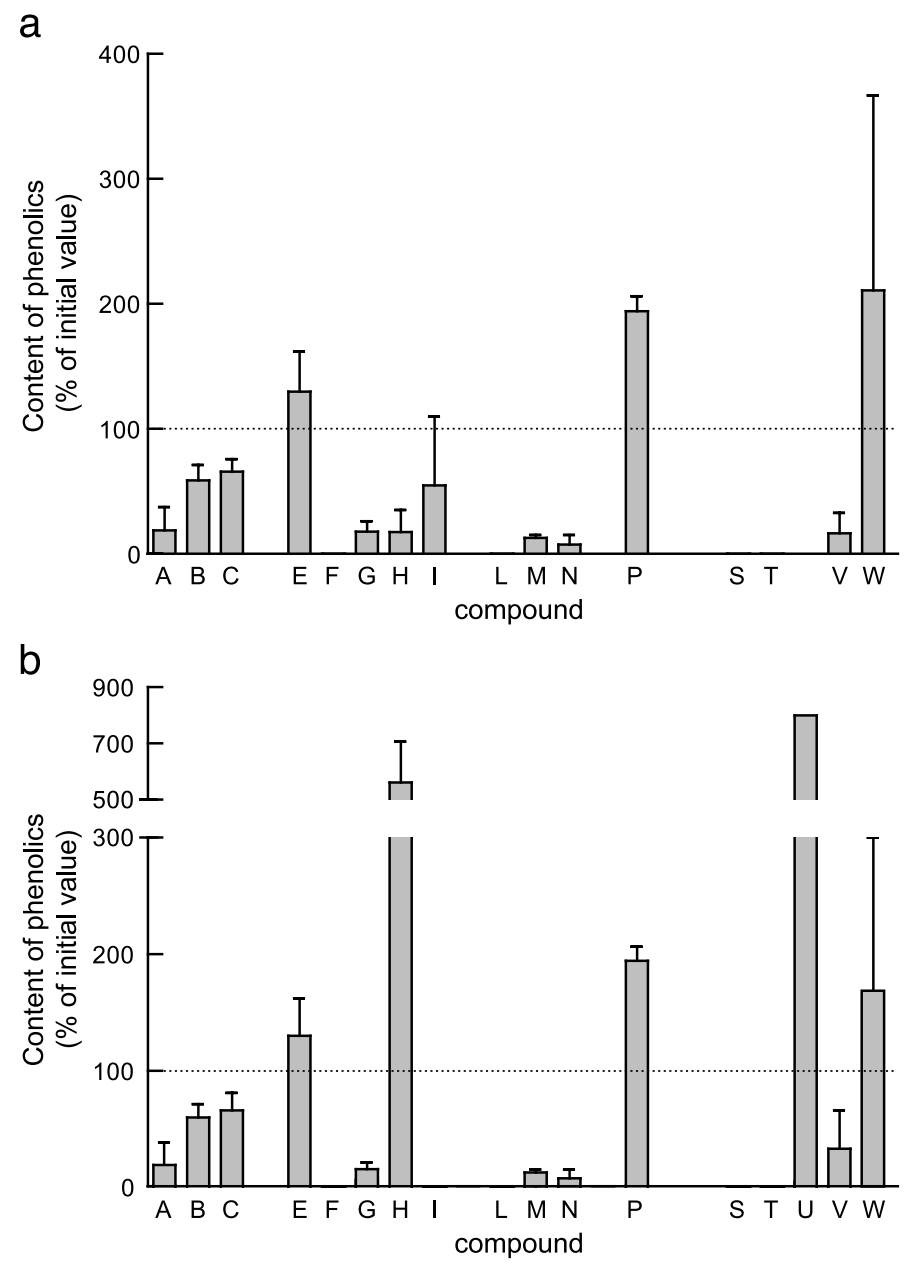

FIG. 3. Change in content of phenolic compounds in leaf litter derived from Quercus (a) and Eucalyptus (b) after 5-d incubation in aquatic environments, with Proasellus coxalis as detritivore, as compared with initial values of the litter $(100 \%)$. Data are median \pm median absolute deviation $(N=9)$. Only those peaks are listed along the $X$-axis that were found in the samples studied here.

degraded, although individual variation was high (Figure 4b), whereas compounds $\mathrm{H}, \mathrm{P}$, and $\mathrm{U}$ were concentrated higher in feces than in the litter $(P<0.01)$.

In the terrestrial environment, only a few compounds were completely leached, degraded, or transformed in animal-free controls (Figure 5b); only compound $\mathrm{G}$ was obtained in higher concentration after the experiment than 

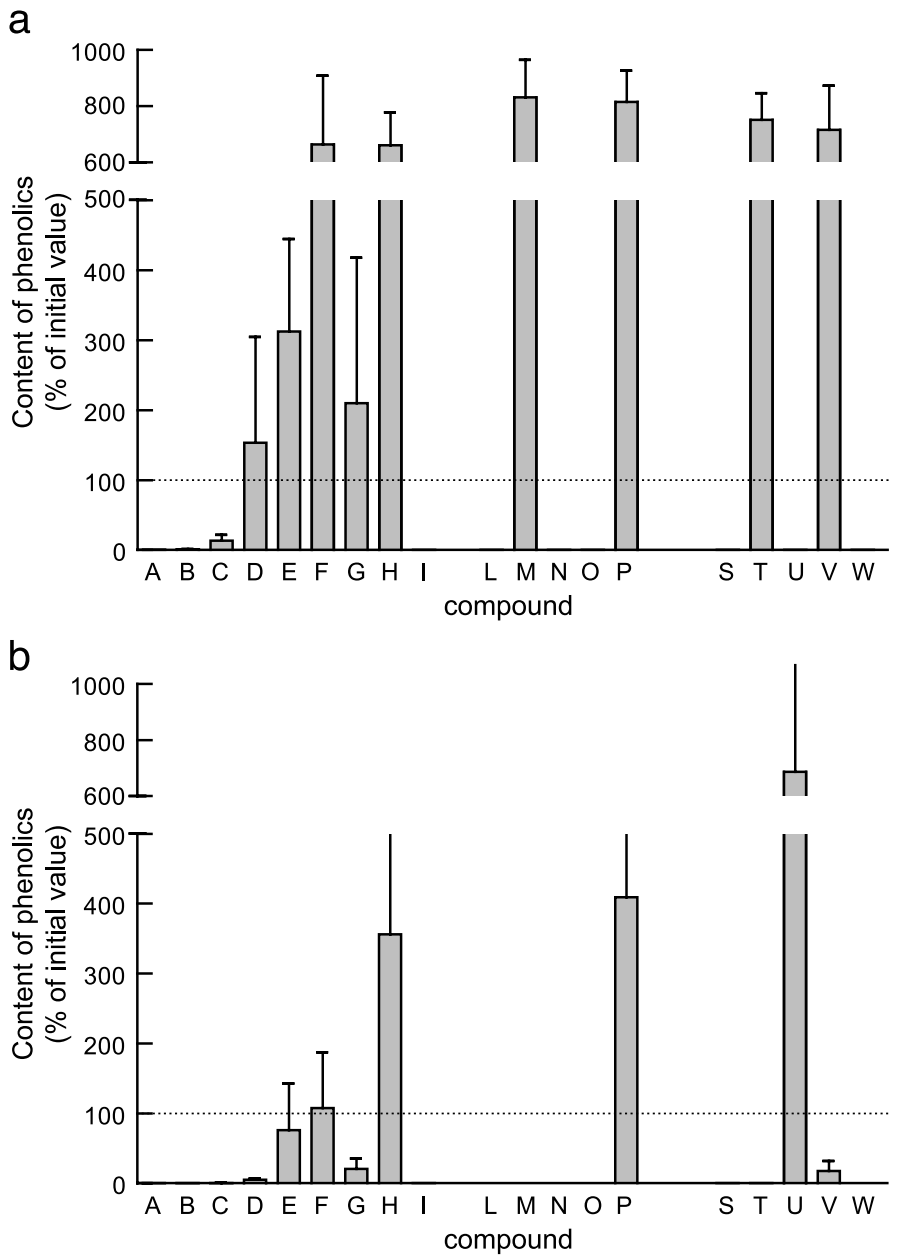

FIG. 4. Change in content of phenolic compounds of leaf litter derived from Quercus (a) and Eucalyptus (b) due to digestive processes by $P$. coxalis as deduced from comparing isopod feces with initial values of the litter $(100 \%)$. Data are median \pm median absolute deviation $(N=9)$. Only those peaks are listed along the $X$-axis that were found in the samples studied here.

before $(P<0.001)$. With Porcellio present (Figure 6b), microbially processed litter was enriched in compounds F, G, and T $(P<0.01)$. With Eluma present, compounds D, P, R, and V were microbially degraded or transformed in the leaf litter that was not consumed by isopods (Figure $7 \mathrm{~b}$ ), whereas compounds B, F, and $\mathrm{T}$ became enriched in the litter $(P<0.01)$. On average, compounds $\mathrm{D}, \mathrm{G}, \mathrm{H}$, 
a

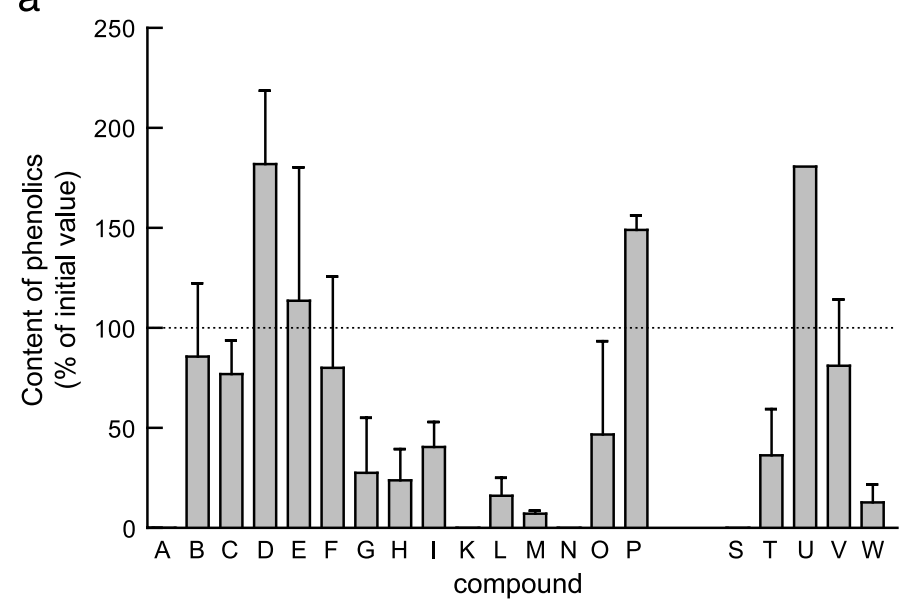

b

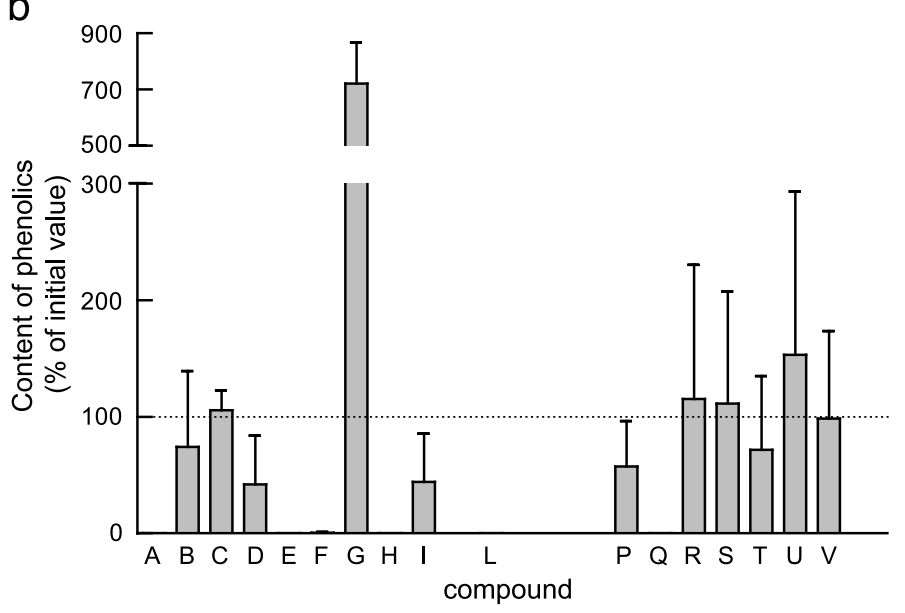

FIG. 5. Change in content of phenolic compounds in leaf litter derived from Quercus (a) and Eucalyptus (b) due to leaching and microbial processing within $5 \mathrm{~d}$ in terrestrial animal-free control assays as compared with initial values of the litter (100\%). Data are median \pm median absolute deviation $(N=9)$. Only those peaks are listed along the $X$-axis that were found in the samples studied here.

$\mathrm{R}, \mathrm{S}$, and $\mathrm{V}$ were digested extensively by Porcellio (Figure $8 \mathrm{~b}$ ), whereas compounds $\mathrm{E}, \mathrm{O}$, and $\mathrm{T}$ were concentrated higher in feces than in litter $(P<$ 0.01). Eluma digested all of the remaining compounds B, G, I, P, R, T, and V, and degraded compound $\mathrm{C}$ almost completely (Figure $9 \mathrm{~b}$ ), but led to a relative increase of compounds $\mathrm{D}, \mathrm{O}$, and $\mathrm{U}(P<0.05)$. 

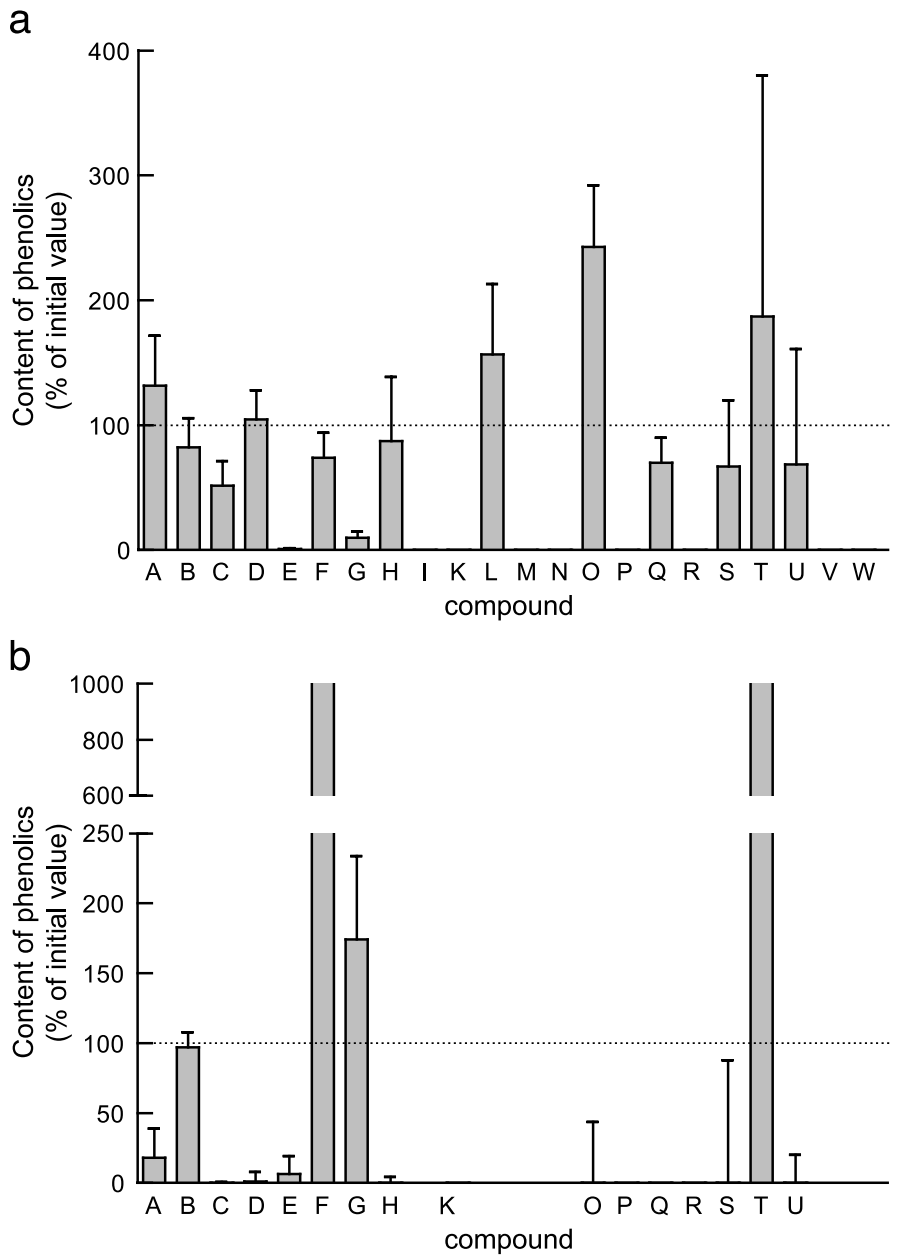

FIG. 6. Change in content of phenolic compounds in leaf litter derived from Quercus (a) and Eucalyptus (b) after 5-d incubation in terrestrial environments, with Porcellio dispar as detritivore, as compared with initial values of the litter $(100 \%)$. Data are median \pm median absolute deviation $(N=9)$. Only those peaks are listed along the $X$-axis that were found in the samples studied here. 
a

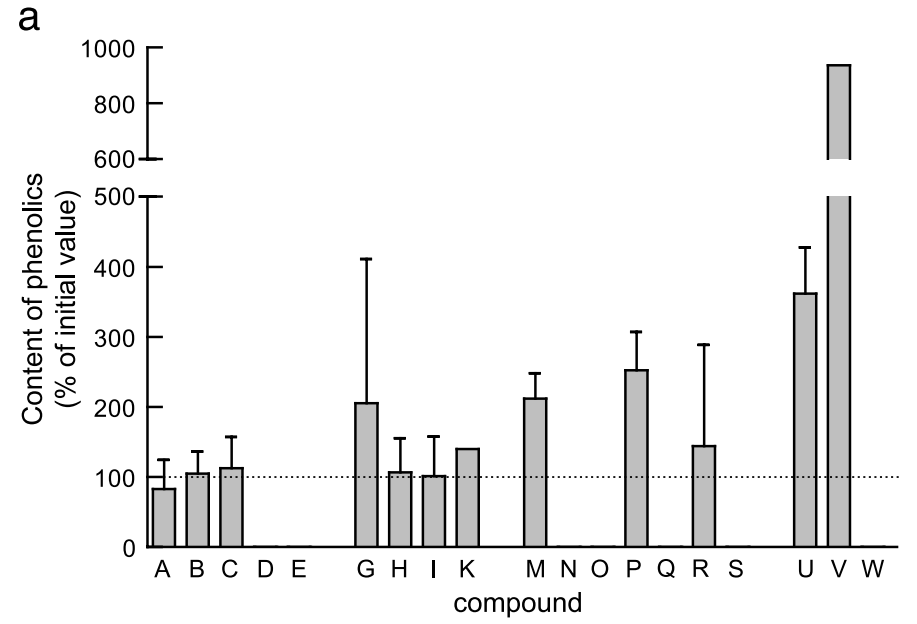

b

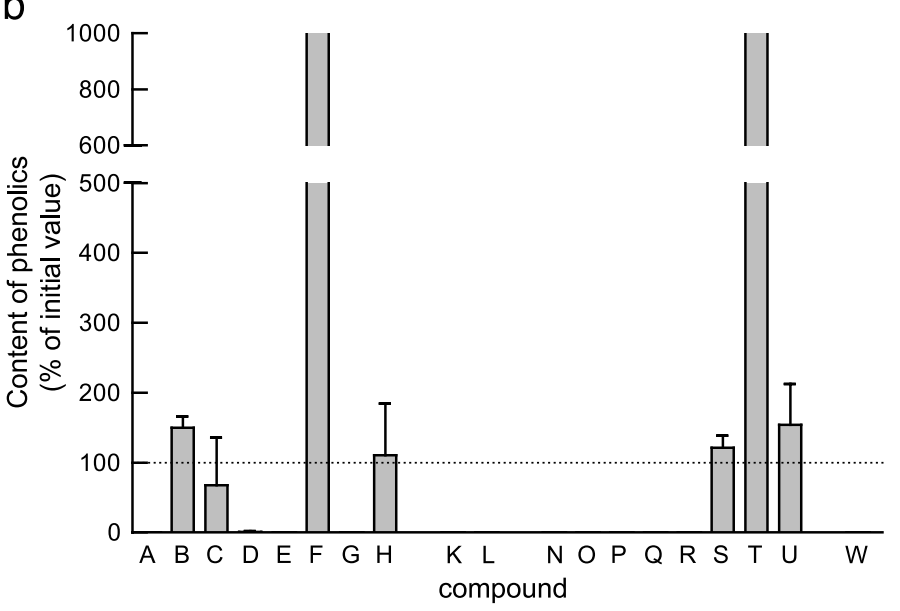

FIG. 7. Change in content of phenolic compounds in leaf litter derived from Quercus (a) and Eucalyptus (b) after 5-d incubation in terrestrial environments, with Eluma caelatum as detritivore, as compared with initial values of the litter $(100 \%)$. Data are median \pm median absolute deviation $(N=9)$. Only those peaks are listed along the $X$-axis that were found in the samples studied here. 
a
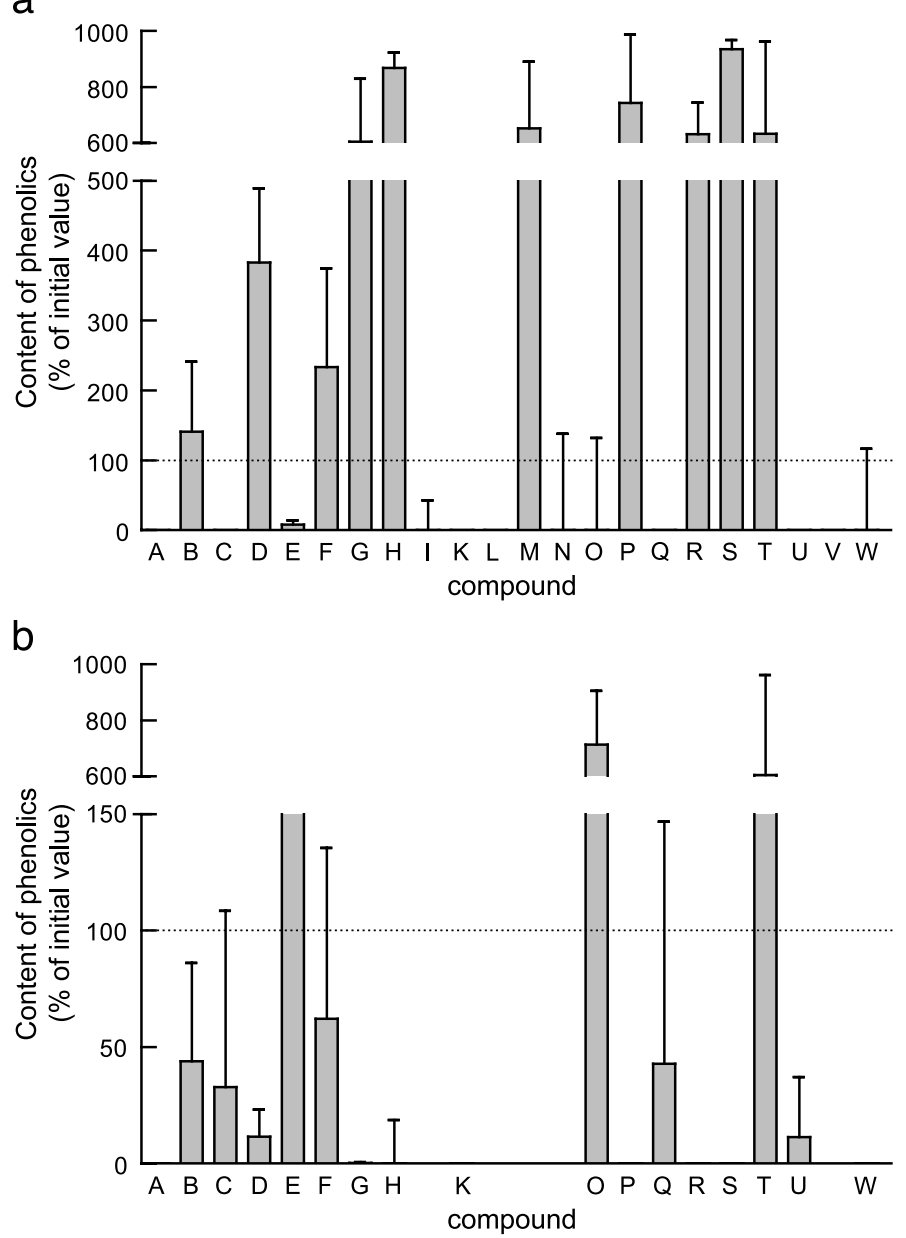

FIG. 8. Change in content of phenolic compounds of leaf litter derived from Quercus (a) and Eucalyptus (b) due to digestive processes by $P$. dispar as deduced from comparing isopod feces with initial values of the litter $(100 \%)$. Data are median \pm median absolute deviation $(N=9)$. Only those peaks are listed along the $X$-axis that were found in the samples studied here. 
a

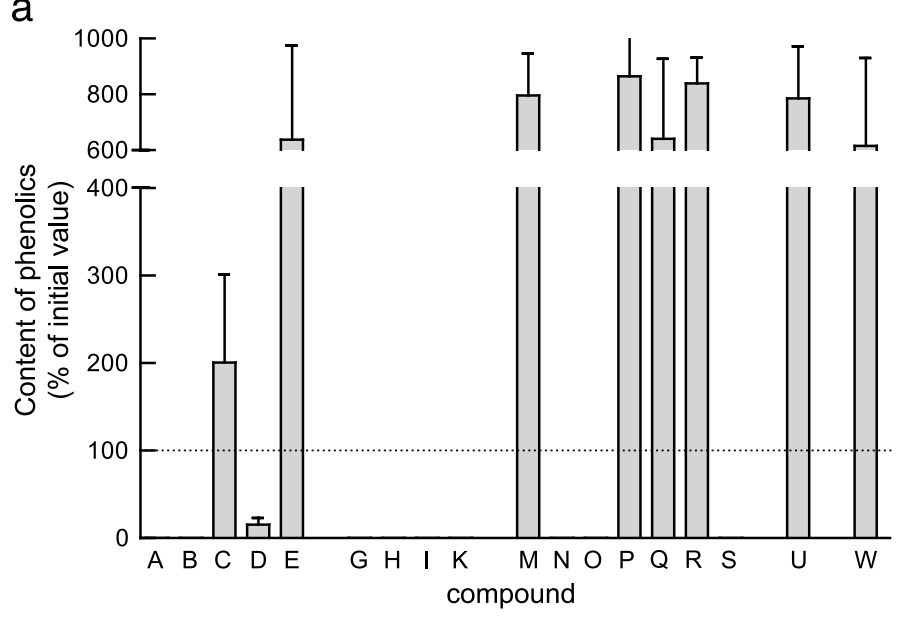

b

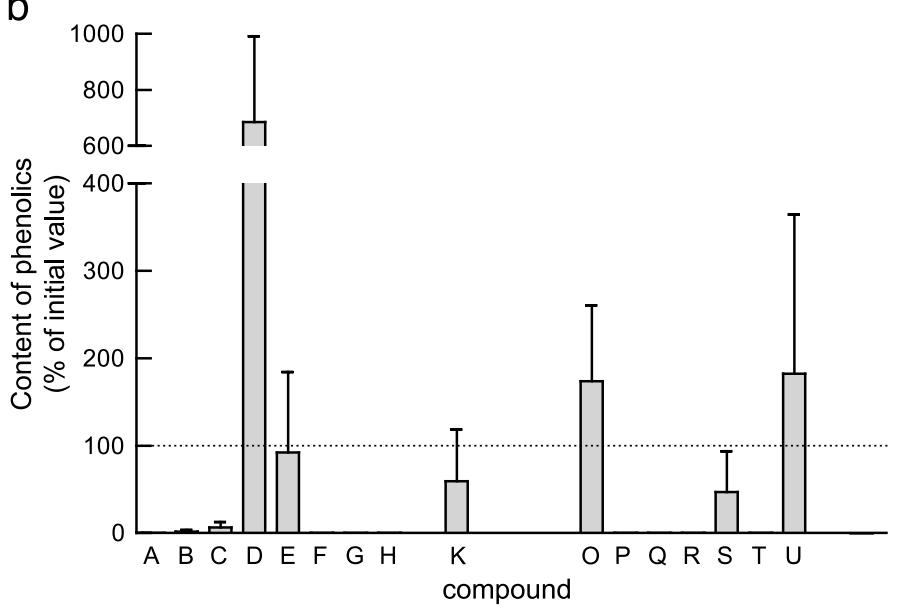

FIG. 9. Change in content of phenolic compounds of leaf litter derived from Quercus (a) and Eucalyptus (b) due to digestive processes by E. caelatum as deduced from comparing isopod feces with initial values of the litter $(100 \%)$. Data are median \pm median absolute deviation $(N=9)$. Only those peaks are listed along the $X$-axis that were found in the samples studied here. 


\section{DISCUSSION}

Degradation of Particular Phenolic Compounds. Owing to the fact that we were unable to unambiguously assign different peaks of our HPLC analysis to distinct phenolic compounds (Table 1), we can only interpret our results based on rough interspecific differences between detritivores and tree species with respect to the reduction and/or increase in particular peaks. However, this information appears sufficient for a first ecosystemic approach to effects of interactions of different detritivores with different leaf litter types. Overall, however, interspecific differences deduced from our present results must be interpreted with caution because we do not know exactly whether the composition of single peaks we obtained by HPLC was the same in leaf litter from Eucalyptus and Quercus.

Ecosystemic Conclusions. The litter of Eucalyptus and Quercus we used in our study did not differ with respect to the overall content of phenolic compounds ( protein-precipitating TA equivalents). The radial diffusion assay as used does not reveal phenol concentrations, but rather provides a measure of protein-binding capacity, and thus, one measure of potential biological activity of a mixture of phenolics that may or may not be correlated with phenol content. Further, tannic acid, which we used here, may not be an appropriate standard for protein precipitation by mixed phenolics because the species studied may differ in both amount and type of hydrolyzable tannins. Yet, comparison of data derived from this method still allows for an estimation of interspecific differences in phenol content or activity, and Domínguez (1994), using different methods, came to a similar conclusion of similar phenol concentrations in Eucalyptus and Quercus. Nevertheless, we found significant differences in consumption rates of these litter types by Proasellus but not in the terrestrial isopods. Thus, it is apparently not the total phenol content that determines detritivore consumption rates, but rather the phenolic signature.

In addition to phenolics (see Introduction), other compounds are considered responsible for mediating consumption and decay rates of plant tissue. While mainly phloroglucinol derivates, such as formylated phloroglucinol and acylphloroglucinol, are considered responsible for feeding deterrence towards mammals (e.g., Pass et al., 1998; Lawler et al., 1999; McLean et al., 2004), different essential oils of Eucalyptus spp. proved active against insect consumers (e.g., Lee et al., 2001; Wang et al., 2001). Whereas purely hydrocarbon components of essential oils (terpenes) are not water-soluble, and thus, will not be lost rapidly through leaching (and would have been present in the leaf litter we used in the present study if they had been so in freshly detached senescent leaves), their oxidized derivates may be leached at early decomposition stages. Thus, those essential oils that are common in E. globulus (e.g., 1,8-cineole and $\alpha$-pinene; Li and Madden, 1995; Lee et al., 2001) are readily leached off litter (as can be deduced from, e.g., Krock et al., 2002; Rasmussen et al., 2003) and 
probably were not present in our experimental litter. Those differences in consumption and digestibility of Eucalyptus and Quercus we observed herein were probably not due to essential oils. On the other hand, the lack of negative effects of Eucalyptus litter on decomposition through isopod feeding may be due to the lack of essential oils that had been lost from litter prior to collection.

According to our present results, phenolics in Eucalyptus appear to be less deterrent to the aquatic isopod, P. coxalis, than phenolics in Quercus (e.g., compounds B or I). In a previous study, Eucalyptus oils had stronger effects on aquatic fungal decomposers than phenolics (Canhoto et al., 2002). As expected, the loss of phenolics through leaching was almost complete and higher in the aquatic than in the terrestrial environment (but apparently had not been extensive under terrestrial conditions prior to litter collection). Thus, negative effects of Eucalyptus phenolics (if any exist) would be expected to be stronger for terrestrial detritivores than for aquatic, but we did not find any effect on consumption or digestibility by terrestrial isopods. From this, we conclude that decomposition of Eucalyptus litter does not proceed more slowly than that of litter from native Portuguese trees. In coincidence, Rezende et al. (2001) did not find significantly different decay rates of leaf litter derived from Eucalyptus grandis, introduced to Brazil, and Dalbergia nigra, a native Brazilian tree, after $1 \mathrm{yr}$.

As expected, we observed significant differences in phenol degradation, both between detritivores and between litter types. Digestive processes and effects on microbial activity obviously differ among detritivores, and both the identity of detritivores and the litter type affect phenol degradation (and probably also other decomposition processes) both directly and indirectly. Consequently, we cannot consider them functionally redundant, although they superficially belong to the same functional group (see Zimmer et al., 2002b, 2004; Chalcraft and Resetarits 2003a,b). Further, different litter types can obviously not substitute for each other in terms of their quality as food to detritivores (see Zimmer et al., 2004).

Overall, however, although the phenolic signature of Eucalyptus litter influences its degradation, we did not find consistent evidence for slowed-down decomposition processes of the litter of this introduced tree species that would have suggested impaired nutrient cycles. Thus, negative effects that Eucalyptus plantation may have on Portuguese forests and freshwater systems are not due to differences in tannins of Eucalyptus litter relative to common native trees.

\section{REFERENCES}

ABElho, M. and GRAÇA, M. A. S. 1996. Effects of Eucalyptus afforestation on leaf litter dynamics and macroinvertebrate community structure of streams in Central Portugal. Hydrobiologia 324:195-204. 
CAmpbell, I. C. and Fuchshuber, L. 1995. Polyphenols, condensed tannins, and processing rates of tropical and temperate leaves in an Australian stream. J. N. Am. Benthol. Soc. 14:174-182.

CANHoto, C. M. and GraÇA, M. A. S. 1996. Decomposition of Eucalyptus globulus leaves and three native leaf species (Alnus glutinosa, Castanea sativa, Quercus faginea) in a Portuguese low order stream. Hydrobiologia 333:79-85.

CAnhoto, C. M. and GRAÇA, M. A. S. 1999. Leaf barriers to fungal colonization and shredders (Tipula lateralis) consumption of decomposing Eucalyptus globulus. Microb. Ecol. 37:163-172.

Canhoto, C. M., ABelho, M., and GraÇA, M. A. S. 2002. Effects of Eucalyptus globulus plantations in low order streams of Central Portugal, pp. 505-514, in M. A. Pardal, J. C. Marques, and M. A. S. Graça (eds.). Aquatic Ecology of the Mondego River Basin: Global Importance of Local Experience. Imprensa da Universidade, Coimbra.

Chalcraft, D. R. and Resetarits, W. J. 2003a. Mapping functional similarity of predators on the basis of trait similarity. Am. Nat. 162:390-402.

Chalcraft, D. R. and Resetarits, W. J. 2003b. Predator identity and ecological impacts: Functional redundancy or functional diversity? Ecology 84:2407-2418.

Conde, E., Cadihaia, E., and Garcia Vallejo, M. C. 1997. Low molecular weight polyphenols in leaves of Eucalyptus camaldulensis, E. globulus and E. rudis. Phytochem. Anal. 8:186-193.

Domínguez, M. T. 1994. Influence of polyphenols in the litter decomposition of autochthonous (Quercus ilex L., Quercus suber L., Pinus pinea L., Cistus ladanifer L., and Halimium halimifolium W.K.) and introduced species (Eucalyptus globulus L., and Eucalyptus camaldulensis D.) in the southwest of Spain. Acta Hortic. (ISHS) 381:425-428. http://www. actahort.org/books/381/381_56.htm.

GRAÇA, M. A. S. 2001. The role of invertebrates on leaf litter decomposition in streams-A review. Int. Rev. Hydrobiol. 86:383-393.

Graça, M. A. S., Pozo, J., CAnhoto, C., and Elosegi, A. 2002. Effects of Eucalyptus plantations on detritus, decomposers and detritivores in streams. Sci. World J. 2:1173-1185.

Hagerman, A. E. 1987. Radial diffusion method for determining tannin in plant extracts. J. Chem. Ecol. 13:437-449.

Koupai-Abyazani, M. R., McCallum, J., and BoHM, B. A. 1992. Identification of the constituent flavonoid units in sainfoin proanthocyanidins by reversed-phase high-performance liquid chromatography. J. Chromatogr. 594:117-123.

Krock, B., SchmidT, S., Hertweck, C., and BALDWIN, I. T. 2002. Vegetation-derived abscisic acid and four terpenes enforce dormancy in seeds of the post-fire annual, Nicotiana attenuata. Seed Sci. Res. 12:239-252.

LAWler, I. R., Eschler, M., Schliebs, D. M., and Foley, W. J. 1999. Relationship between chemical functional groups on Eucalyptus secondary metabolites and their effectiveness as marsupial antifeedants. J. Chem. Ecol. 25:2561-2573.

LeE, B.-H., ChOI, W.-S., LEE, S.-E., and PARK, B.-S. 2001. Fumigant toxicity of essential oils and constituent compounds towards the rice weevil, Sitophilus oryzae (L.). Crop Port. 20:317-320.

Li, H. and Madden, J. L. 1995. Analysis of leaf oils from a Eucalyptus species trial. Biochem. Syst. Ecol. 23:167-177.

Mclean, S., Brandon, S., Davies, N. W., Foley, W. J., and Muller, H. K. 2004. Jensenone: Biological reactivity of a marsupial antifeedant from Eucalyptus. J. Chem. Ecol. 30:19-177, 2004.

Mellilo, J. M., Aber, J. D., and Mauratore, H. J. F. 1982. Nitrogen and lignin control of hardwood leaf litter decomposition dynamics. Ecology 63:621-626.

Pass, D. M., Foley, W. J., and Bowden, B. 1998. Vertebrate herbivory on EucalyptusIdentification of specific feeding deterrents for common ringtail possums (Pseudocheirus peregrinus) by bioassay-guided fractionation of Eucalyptus ovata foliage. J. Chem. Ecol. 24:1513-1527. 
Pinto, C., Sousa, J. P., GraÇA, M. A. S., and DA Gama, M. M. 1997. Forest soil Collembola: does tree introduction make a difference? Pedobiologia 41:131-138.

Rasmussen, L. H., Jensen, L. S., and Hansen, H. C. B. 2003. Distribution of the carcinogenic terpene ptaquiloside in bracken fronds, rhizomes (Pteridium aquilinum), and litter in Denmark. J. Chem. Ecol. 29:771-778.

Rezende, J. L. P., GARCIA, Q. S., and SCOTTI, M. R. M. M. L. 2001. Laboratory decomposition of Dalbergia nigra Ail. ex. Benth and Eucalyptus grandis W. Hill ex. Maiden leaves in forest and eucalypt plantation soil. Acta Bot. Bras. 15:305-312.

Sasikumar, K., Vijayalakshmi, C., and Parthiban, K. L. 2002. Allelopathic effects of Eucalyptus on blackgram (Phaseolus mungo L.). Allelopathy J. 9:205-214.

Scalbert, A., Monties, B., and FaVre, J.-M. 1988. Polyphenols of Quercus robur: adult tree and in vitro grown calli and shoots. Phytochemistry 27:3483-3488.

Sousa, J. P., Vingada, J. V., Barrocas, H., and DA Gama, M. M. 1997. Effects of introduced exotic tree species on Collembola communities: the importance of management techniques. Pedobiologia 41:145-153.

Streit, W. and Fengel, D. 1994. Purified tannins from quebracho colorado. Phytochemistry 36:481-484.

TANaKa, N., Shimoura, K., and Ishimaru, K. 1995. Tannin production in callus cultures of Quercus acutissima. Phytochemistry 40:1151-1154.

VAN Alstyne, K. L. 1995. Comparison of three methods for quantifying brown algal polyphenolic compounds. J. Chem. Ecol. 21:45-58.

van de Casteele, K., De Loose, R., and van Sumere, C. 1983. Separation of some anthocyanidins, anthocyanins, proanthocynidins and related substances by reversed-phase highperformance liquid chromatography. J. Chromatogr. 259:291-300.

WANG, J.-J., TSAI, J. H., ZHAO, Z.-M., and LI, L.-S. 2001. Toxic effects of six plant oils allone and in combination with controlled atmosphere on Liposcelis bostrychophila (Psocoptera: Liposcelididae). J. Econ. Entomol. 94:1296-1301.

ZIMMER, M. 2003. Habitat and resource use by terrestrial isopods(Isopoda: Oniscidea), pp. 243-261, in S. Sfenthourakis, P. B. de Araujo, E. Hornung, H. Schmalfuss, S. Taiti, and K. Szlávecz (eds.). The Biology of Terrestrial Isopods (Crustaceana Monographs 2). Brill Academic Publishers, Leiden.

ZIMMER, M. and BARTHOLMÉ, S. 2003. Bacterial endosymbionts in Asellus aquaticus (Isopoda) and Gammarus pulex (Amphipoda), and their contribution to digestion. Limnol. Oceanogr. 48:2208-2213.

Zimmer, M. and Huryn, A. D. Consumption, assimilation, respiration and defecation, in M. O. Gessner, F. Bärlocher, and M. A. S. Graça (eds.). Methods in Ecology: Litter Decomposition in Aquatic Ecosystems. Blackwell, in press.

Zimmer, M., Danko, J. P., Pennings, S. C., Danford, A. R., Carefoot, T. H., Ziegler, A., and UGLOW, R. F. 2002a. Cellulose digestion and phenol oxidation in coastal isopods (Crustacea: Isopoda). Mar. Biol. 140:1207-1213.

Zimmer, M., Pennings, S. C., Buck, T. L., and Carefoot, T. H. 2002b. Species-specific patterns of litter processing by terrestrial isopods (Isopoda: Oniscidea) in high intertidal salt marshes and coastal forests. Funct. Ecol. 16:596-607.

Zimmer, M., Pennings, S. C., Buck, T. L., and Carefoot, T. H. 2004. Salt marsh litter and detritivores: a closer look at redundancy. Estuaries. 27:753-769. 